\title{
Neuralgic amyotrophy triggered by hepatitis $E$ virus: a particular phenotype
}

\author{
Authors: \\ Quentin Scanvion $^{1}$; Thierry Perez ${ }^{2}$; François Cassim ${ }^{3}$; Olivier Outteryck $^{4}$; Aurélia Lanteri ${ }^{1}$; Pierre- \\ Yves Hatron ${ }^{1}$; Marc Lambert ${ }^{1}$; Sandrine Morell-Dubois ${ }^{1}$. \\ Affiliations: \\ ${ }^{1}$ Internal Medicine Department, National Reference Center for Rare Autoimmune Systemic Diseases, FHU \\ IMMINeNT \\ ${ }^{2}$ Pneumology Department \\ ${ }^{3}$ Neurophysiology Department \\ ${ }^{4}$ Neurology Department \\ Lille University Hospital, Medical School Henri Warembourg, F-59000 LILLE, France.

\section{Corresponding author} \\ Quentin Scanvion \\ University of LILLE, Medical school Henri Warembourg, Internal Medicine Department \\ CHRU, F-59000 LILLE, France \\ E-mail: quentin.scanvion@gmail.com,
}

Key words: Brachial neuritis, Parsonage-Turner syndrome, peripheral neuropathies, HEV, phrenic paresis.

\section{Author Contributions:}

Conception and design: Quentin Scanvion and Sandrine Morell-Dubois. Collection data (case report): Quentin Scanvion, Thierry Perez, François Cassim, Olivier Outteryck, Aurélia Lanteri, Pierre-Yves Hatron, Marc Lambert and Sandrine Morell-Dubois. Collection and assembly of data (review): Quentin Scanvion. Data analysis: Quentin Scanvion. Interpretation: Quentin Scanvion and Sandrine Morell. Manuscript drafting: Quentin Scanvion and Sandrine Morell-Dubois. Final approval of manuscript: Quentin Scanvion, Thierry Perez, François Cassim, Olivier Outteryck, Aurélia Lanteri, Pierre-Yves Hatron, Marc Lambert and Sandrine Morell-Dubois.

\section{Acknowledgements:}

The authors thank Laura Ravasi who provided medical writing services and Hélène Béhal for statistical advice on behalf of the University of Lille.

They are grateful to the National Reference Center for Hepatitis E Virus in Toulouse, France for HEV genotype analysis.

\section{Conflicts of interest:}

All authors report no disclosures relevant to the manuscript.

Funding source: None 


\section{Abstract}

Objective: The neuralgic amyotrophy may be of difficult diagnosis, due to phenotypic variability, with different initial presentations (upper plexus multiple mononeuropathy, lumbosacral involvement, distal reached, phrenic involvement). To date, there is little guidance on these patients' therapeutic management, especially those for which neuralgic amyotrophy is triggered by hepatitis E virus (HEV-NA). The study aims to identify specific features that characterize patients bearing the neuralgic amyotrophy triggered by HEV. Methods: We first describe a new case report of HEV-neuralgic amyotrophy, with delayed diaphragmatic reach. Then, the literature was searched for reports of HEV-NA $(n=39)$, and neuralgic amyotrophy with phrenic paresis $(n=42)$ from 1999 to June 2016. Relevant data were retrieved, analyzed and compared with the parameters of idiopathic neuralgic amyotrophy ( $\mathrm{n}=199)$ of the largest cohort, described by Van Alfen and Van Engelen in 2006. Results: Compared to the published cohort, HEV-NA patients were more likely to be men (M/F 34/5 versus $136 / 63$, p=0.017), with more frequent bilateral symptoms $(86.8 \%$ cases versus $28.5 \%, \mathrm{p}<0.0001)$ as well as phrenic paresis $(18.0 \%$ versus $6.6 \%, \mathrm{p}=0.028$ ). The clinical improvement is poor, with $15.6 \%$ of cases with remission only. Conclusions: A particular phenotype characteristic of the HEV-induced neuralgic amyotrophy has arisen. Our findings call for action in validating the above mentioned features that illustrate the HEV-NA cases as an early diagnosis would prevent complications, especially the phrenic damage often associated with a worse functional outcome. 


\section{Manuscript}

\section{Introduction}

The neuralgic amyotrophy syndrome (NA) is an acute multiple mononeuropathy predominantly affecting the brachial plexus described around 1880. An intensive neuropathic pain in the scapular area or upper arm, often exacerbated at night and when arm is at rest, is generally followed by multifocal paresis (stereotypically including the serratus or infrascapular muscles) and/or hypoesthesia, then an amyotrophy. However, several distinct subtypes can occur - as with phrenic nerves involvement - and generate the NA phenotypic variability [1].

In fact, there are 2 forms of NA: (i) the hereditary neuralgic amyotrophy (HNA) associated with a mutation in the SEPT9 gene, on chromosome 17q25, in 55\% of families [2]; and (ii) the idiopathic form (INA), also known as brachial neuritis or Parsonage-Turner syndrome (the eponymous names of the authors of the first case series, 1948). A 1/1000/year incidence, previously underestimated, has recently been reported [3].

The exact etiopathogenesis is unknown, but post infectious immune reactions are frequent (HIV, Cytomegalovirus, Epstein-Barr virus, parvovirus B19, Campylobacter, Yersinia, Borrelia) [2]. Recurrences happen in 30-40\% patients with INA [4,5] mostly athletic, therefore mechanical factors and an individual genetic susceptibility are assumed [1,6].

Hepatitis E virus (HEV) infection could trigger many NA. HEV has been found in 10\% NA patients [7] and it is the leading cause of hepatitis worldwide (50\%) [6]. It also accounts for an autochthonous emerging disease, spreading through industrialized countries (genotype 3, 4) [8]. Animals account for the primary reservoir, for instance $65 \%$ French pigs are HEV+ [9]. Although usually asymptomatic, genotype 3-HEV extrahepatic and neurological involvement has been reported more frequently since $2000[8,10]$.

The study seeks to identify whether specific clinical features characterize patients bearing INA triggered by HEV, implying the arise of a specific phenotype.

\section{Methods}

The case of a man referred to the university hospital of Lille, France with INA induced by hepatitis E associated with a bilateral phrenic nerves involvement has been thoroughly described.

Additionally, a review of the literature was performed in June 2016, by searching the following combinations of keywords:

A] (((neuralgic amyotrophy) OR brachial neuritis) OR parsonage turner) AND ((hepatitis E) OR HEV). 
B] (((neuralgic amyotrophy) OR brachial neuritis) OR parsonage turner) AND (phrenic OR diaphragmatic).

No date or language restriction was used for A] as opposed to B] where search was restricted to English articles on Pubmed from 1999 to 2016. After deletion of duplicates, we grouped all case-reports of INA induced by hepatitis E (A) and all cases reports of INA with phrenic paresis (B), including our patient.

The following features (i.e. gender ratio, mean age, prevalence of phrenic paresis, bilateralism and average transaminases in group A; prevalence of bilateral phrenic paresis in group B; and pain duration and clinical improvement (with the median of follow-up) in both groups) were analyzed with respect to those of the largest cohort of NA available, described by Van Alfen and Van Engelen in 2006 [4]. Quantitative variables are expressed as mean \pm standard deviation (SD). Qualitative variables are expressed as frequencies and percentages. Gender ratio and proportion of bilateral and asymmetric NA were compared using Chi-square test. Fisher Exact test was used to compare proportion of painless and proportion of phrenic paresis. The Student's $t$ test was used to compare mean age. In particular for the historic cohort, SD was estimated from the range (range/4) as such data was unavailable. Statistical testing was done at the two-tailed $\alpha$ level of 0.05 and data were analyzed using the SAS software package, release 9.3 (SAS Institute, Cary, NC).

\section{Results}

\section{Case report}

A 42-year-old athletic (marathon, tennis) man rushed to emergency on October $1^{\text {st }}, 2015$ at night, stating a brutal, non-traumatic and very intense (numeric rating scale 10/10) para-spinal cervicothoracic, predominantly right back pain, associated with vagal symptoms (nausea, vomiting). His medical records revealed a 20 -year-old malaria (Plasmodium falciparum) episode and a penicillin allergy (skin rash) without any relevant neurological family history.

Chest emergencies, including dissecting aorta were excluded. Neither pleural or parenchymal injury nor osteolytic or sclerotic foci were revealed. Intravenous morphine was administered to ease the pain. Soon after $(<24 \mathrm{~h})$, the patient described transient paresthesiae in the right arm, hypoesthesiae of the right thenar eminence and inside of the left knee (territory of the saphenous nerve). Decreased deep tendon reflexes of the upper limbs and moderate high dysphagia were reported with neither amyotrophy nor pyramidal irritation. Brain MRangiography and cerebrospinal fluid analysis excluded myelitis or subarachnoid hemorrhage. EMG did not reveal any signs of demyelination or neuropathy on any limb. However, the serratus anterior, infraspinatus, flexor pollicis longus and pronator quadratus (high-yield muscles for NA) had not been EMG-explored at that time. 
Biological analysis depicted a sharp hepatic cytolysis and a moderate cholestasis, with no fulminant hepatitis. Lactate dehydrogenase (350 IU/L) and creatine kinase (260 IU/L) were also increased. Blood and PCR analyses excluded HBV, HCV, HIV, VZV, CMV, HSV, EBV, parvovirus B19, HHV6, HHV8, Borrelia, syphilis, ANCA, antinuclear antibodies, antibodies associated with autoimmune hepatitis as well as an inflammatory syndrome, thrombocytopenia $\left(125,000 / \mathrm{mm}^{3}\right)$, lymphopenia $\left(500 / \mathrm{mm}^{3}\right)$ with $10 \%$ mononucleosis-like cells. IgM were increased to $4.06 \mathrm{~g} / \mathrm{L}$, along with a monoclonal $\operatorname{IgM}-\lambda$ spike on the blood protein electrophoresis.

Transferred to the internal medicine department, the patient narrated he had spent three weeks in Corsica in August. Further analyses were run to test for HAV, Hantavirus, Chikungunya, Leptospirosis, Enterovirus and HEV. HEV serology (IgM and IgG), confirmed by positive blood RT-PCR (32.100 replicas/mL) confirmed acute hepatitis E. Genotyping attested a subtype 3f. The infection was recognized via the Corsican sausage (Figatelli) consumption 5 to 8 weeks prior to the symptoms.

The intermittent spinal pain lasted for a week with a subsequent spontaneous, progressive improvement of the pain along with the liver parameters. The MRI revealed isolated T2 STIR hypersignal of the right infraspinatus, with no signs of muscular atrophy, suggesting myositis.

In November, the patient had no pain, no amyotrophy, no more paresthesia and biology revealed the normalization of lymphocytes, IgM, electrophoresis, the inversion IgM/IgG on HEV serology and the decrease of RT-PCR (1000 replicas $\left./ \mathrm{mm}^{3}\right)$.

In January, the patient referred orthopnea, paradoxical breathing and dyspnea on exertion with a gradual appearance since he had been dismissed in November. Respiratory function tests revealed forced vital capacity, 5.15L (i.e. $92 \%$ predicted), with $50 \%$ decrease in the supine position; total lung capacity, $7.42 \mathrm{~L}$ (94\% predicted); forced expiratory volume in 1 second, $4.3 \mathrm{~L}$ ( $83 \%$ predicted). The global inspiratory muscle strength was low in voluntary moves, with a PImax (maximum inspiratory pressure) of $63 \mathrm{cmH}_{2} \mathrm{O}$ (predicted=105 $\mathrm{cmH}_{2} 0$ ). His sniff nasal pressure was underperforming. The phrenic EMG confirmed the left paralysis (no motor potential after stimulation) and the very severe right paresis.

A final diagnosis of HEV-induced INA with severe bilateral phrenic paresis was established. The patient was offered physiotherapy and respiratory rehabilitation, with no treatment for hepatitis as RT-PCR was negative at that time.

At the 12-month-follow up visit, there were no motor deficits, no amyotrophy, and full recovery of the tendon reflexes. Nonetheless, hypoesthesia persisted, and the phrenic paresis had clinically moderately 
improved. Supine fall of forced vital capacity improved at $25 \%$ and maximal inspiratory pressure was normalized at $123 \mathrm{cmH}_{2} 0$. The left phrenic paralysis decreased.

\section{Review of the relevant literature}

Thirty-eight cases (group A) relating HEV-induced INA and 41 cases (group B) reporting INA with phrenic paresis were found in the literature. Sources and characteristics are detailed in the table $1[6,7,11-32]$ and appendix table e-1, respectively. The features of each group are described in table 2.

The patients with HEV-INA were 46 years old (46 \pm 9.8$)$, with statistically more males $(87.2 \%)$ than INA of all etiologies $(68.3 \%)$ and the syndrome is more frequently bilateral and asymmetric (86.8\% vs $27.7 \%)$. A phrenic paresis is more frequently reported: $18.0 \%$ (7/39), vs $6.6 \%$. The clinical improvement is poor: remission only occurs in $15.6 \%$ cases over a 10 month follow-up. The cytolysis predominates on the ALT with a $2 / 1$ ratio.

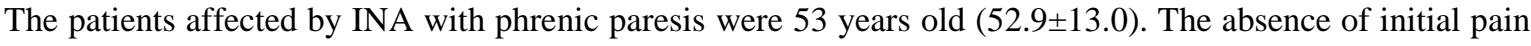
$(23.8 \%)$ emerges as a peculiar feature of this group.

\section{Discussion}

Our case report illustrates the phenotypic variability of NA and underlines the difficulty of a prompt diagnosis. The two essential criteria are: a typical pain (acute onset of very severe and analgesic-resistant pain in the shoulder area) and a multifocal sensory and/or motor neuropathy [1]. Other signs are optional. Amyotrophy depends on motor neuropathic impairment. Electrophysiological support findings are not fundamental because negative results are often due to sampling error [1]: it is essentially a clinical diagnosis. In our case, the NA initial presentation combines several subtypes: a pure sensory form (patient did not show motor weakness or amyotrophy of limbs); a lumbosacral involvement (8.2\% of cases, and only $<6.7 \%$ for sensory signs [4]) with anesthesia of the territory of the left saphenous nerve; a distal reached (thenar hypoesthesia); an involvement of the cranial nerves $(<2.6 \%$ of cases [4]) with a brief high dysphagia. In addition, when the phrenic involvement occurs, it exacerbates the severity of the syndrome.

The analysis of the literature review has yielded to a particular phenotype for the HEV-induced INA that is described by: a prevalence of men, moderately older, a bilateral and very asymmetric form, and a frequent phrenic nerve involvement.

Our findings are in agreement with a previous suggestion reported by Van Alfen et al. derived from their large cohort: “...there were the grossly elevated liver enzymes for which no cause could be identified in 10 , usually male, patients, most of whom seemed to have a clinical subtype of NA with extensive bilateral brachial 
plexus and phrenic nerve involvement. This subtype may be triggered by a specific but unknown antecedent infection that also causes a transient hepatitis" [4].

At that time, HEV had not yet been identified (and the HEV-INA prevalence was unknown.) In the past decade, HEV has been reported to (i) trigger neurological disorders including Guillain-Barre syndrome, meningoencephalitis and INA and (ii) to be implicated in extra hepatic manifestations [10,28]. In fact, research on HEV has recently evidenced the HEV neurotropism by proving its capability of replicating, assembling and entering specific nervous system-derived cells [33]. Another hypothesis is that HEV may promote INA in predisposed people [6]. Recent guidelines recommend to systematically search HEV for all INA [10].

Overall, this literature review suggests that the phrenic paresis is an important symptom in the phenotype HEV-INA. This preponderance may be underestimated because some cases with phrenic paresis within the historic cohort could have been triggered by HEV. Ten patients were described with hepatitis [4] but HEV like etiology was unknown in 2006. In contrast, the increased prevalence of phrenic involvement in this subgroup must be moderated. Now Van Eijk et al. estimate $10 \%$ of phrenic reached in their current cohort $(>1,200$ patients), but they don't precise the proportion of HEV or HNA [1]. This impairment not uncommon in HNA family (14\%) [4], could overestimate the prevalence of our group A (cases 30 and 33 suggest a possible HNA, but no mutation of the SEPT9 gene were found [6]). The neuralgic amyotrophy physiopathology associates biomechanical factors (on the plexus brachial) to an immune trigger [1,2]. The authors hypothesize that the strong neurotropism of HEV may induce a more diffuse form of neurologic disorders. The phrenic involvement is likely the most symptomatic, therefore the most often diagnosed and mentioned, but not the only one (like the transient high dysphagia of our patient).

Furthermore, NA is a disease of young adults (35-40 years on average) [4,34] although those with INA triggered by HEV tend to be on the older side of such young adulthood. On the other hand, hepatitis E more frequently affects older patients (median age 64 years for Woolson et al. [24]) however, those patients with neurological manifestations tend to be among the younger ones. This curiously overlap seems to correspond to a population that interesting matches most of the reported HEV-INA cases.

The general characteristics of HEV-INA phenotype appear independent of phrenic involvement. When all INA with phrenic involvement are considered, the hereby reviewed cases are older subjects, as previously reported in two small series [35,36] of 19 patients (mean age 59.5 and 61 years, respectively). As described in our case, a symptomatic phrenic involvement may appear much later than the hepatitis E. Moreover, pain was 
not reported in many cases of group B. We can suggest that some asymptomatic hepatitis E has gone misdiagnosed.

A better understanding of this NA phenotype seems crucial to early diagnose HEV-INA. In fact, in our case the clinical picture has been confused with HEV-induced myositis, as it has previously been described [37].

Recovery of strength is rather slow (several years) and often incomplete as pain, disabilities, little residual paresis or intolerance to effort are still present in 3 patients out of 5 [2,5]. A worse prognosis is linked to phrenic involvement $[1,35,38]$, which accounts for a severity factor affecting sport and work abilities and leading to a worse quality of life and sleep. It is therefore necessary to be aware of and search for phrenic involvement, especially in cases of hepatitis E.

There is no current treatment for NA. A combination of nonsteroidal anti-inflammatory drugs and opiate is the best symptomatic option to treat initial neuropathic pain [4]. It is uncertain whether a short corticotherapy at NA onset decrease the symptom duration [39] and it has been reported as non-effective on phrenic damage [38].

Acute hepatitis E doesn’t usually require a specific treatment. In general, immunocompromised patients are to be treated because of the risk of chronic hepatitis. In particular, ribavirin is effective on acute or chronic HEV [40]. However, we are still debating whether patients with extra-hepatic manifestations should be treated for HEV. Strong arguments in favor of treating male patients are poor clinical improvement of INA and rather great proportion of phrenic nerve damage. As a continuous effort to (i) decrease neurological symptoms, (ii) improve quality of life and (iii) decrease overall sick leave, we feel that stronger therapeutic studies for INA triggered by HEV and guidelines are required. In fact, only empirical treatments are currently available in the literature.

The multiple limitations of a retrospective analysis of cases of independent publications must be considered (missing information and misclassification, publication bias and risk of non-representability and evaluation bias). We suggest that our observational findings be supported by prospective studies with multivariate analysis.

At this time, it seems that a particular phenotype for the INA induced by HEV has emerged: male with bilateral and asymmetric type, and a frequent phrenic nerve involvement. The excess risk of phrenic paresis supports the HEV earlier and curative treatment in addition to the symptomatic therapy.

\section{References}

1. Van Eijk JJJ, Groothuis JT, Van Alfen N (2016) Neuralgic amyotrophy: An update on diagnosis, pathophysiology, and treatment. Muscle Nerve 53:337-350.

2. Van Alfen N (2011) Clinical and pathophysiological concepts of neuralgic amyotrophy. Nat Rev Neurol $7: 315-322$.

3. Van Alfen N, Van Eijk JJJ, Ennik T, et al (2015) Incidence of neuralgic amyotrophy (Parsonage Turner syndrome) in a primary care setting - A prospective cohort study. PLoS ONE Epub 10:e0128361. 
4. Van Alfen N, Van Engelen BGM (2006) The clinical spectrum of neuralgic amyotrophy in 246 cases. Brain 129:438-450.

5. Cup EH, Ijspeert J, Janssen RJ, et al (2013) Residual complaints after neuralgic amyotrophy. Arch. Phys Med Rehabil 94:67-73.

6. Dartevel A, Colombe B, Bosseray A, et al (2015) Hepatitis E and neuralgic amyotrophy: Five cases and review of literature. J Clin Virol 69:156-164.

7. Van Eijk JJJ, Madden RG, Van Der Eijk AA, et al (2014) Neuralgic amyotrophy and hepatitis E virus infection. Neurology 82:498-503.

8. Dalton HR, Webb GW, Norton BC, Woolson KL (2016) Hepatitis E virus: time to change the textbooks. Dig Dis 34;308-316.

9. Rose N, Lunazzi A, Dorenlor V, et al (2011) High prevalence of hepatitis E virus in French domestic pigs. Comp. Immunol. Microbiol Infect Dis 34:419-427.

10. Kamar N, Marion O, Abravanel F, Izopet J, Dalton HR (2016) Extrahepatic manifestations of hepatitis E virus. Liver Int 36:467-472.

11. Fong F, Illahi M (2009) Neuralgic amyotrophy associated with hepatitis E virus. Clin Neurol Neurosurg 11:193-195.

12. Rianthavorn P, Thongmee C, Limpaphayom N, Komolmit P, Theamboonlers A, Poovorawan Y (2010) The entire genome sequence of hepatitis E virus genotype 3 isolated from a patient with neuralgic amyotrophy. Scand J Infect Dis 42:395-400.

13. Kamar N, Bendall RP, Peron JM, et al (2011) Hepatitis E virus and neurologic disorders. Emerg Infect Dis 17:173-179.

14. Carli P, Landais C, Poisnel E, et al (2012) Le syndrome d'Aesculape. Revue de Médecine Interne $33: 111-114$.

15. Inghilleri ML, Grini Mazouzi M, Juntas Morales R (2012) [Neuralgic amyotrophy as a manifestation of hepatitis E infection]. Rev Neurol (Paris) 168:383-384.

16. Cheung MCM, Maguire J, Carey I, Wendon J, Agarwal K (2012) Hepatitis E - an unexpected problem at home. Scand J Gastroenterol 47:253-253.

17. Peri AM, Milazzo L, Meroni L, Antinori S (2013) Radiculoneuropathy associated with acute hepatitis E. Dig Liver Dis 45:963-964.

18. Deroux A, Belbézier a, Hyerle L et al (2013) Hépatite E et troubles neurologiques : une association à ne pas méconnaître ! Revue de Médecine Interne 34(suppl2):A59-A60.

19. Valence M, Cador B, Jezequel C, Pinel JF, Jego P (2014) Syndrome de Parsonage et Turner et hépatite E : un nouveau cas. Revue de Médecine Interne 35(suppl2):A124-A125.

20. Chirio D, Demonchy E, Laffon M, et al (2014) Syndrome de Parsonage Turner et hépatite E : à propos de deux cas. Revue de Médecine Interne 235(suppl2):A124-A124.

21. Motte A, Franques J, Weitten T, Colson P (2014) Hepatitis E-associated Parsonage-Turner syndrome, France. Clin Res Hepatol Gastroenterol Epub 38:e11-e14. 
22. Moisset X, Vitello N, Bicilli E, et al (2014) Case Report: Severe bilateral amyotrophic neuralgia associated with major dysphagia secondary to acute hepatitis E. F1000Research 2014 Jan.

23. Deroux A, Brion JP, Hyerle L, et al (2014) Association between hepatitis E and neurological disorders: Two case studies and literature review. J Clin Virol 60:60-62.

24. Woolson KL, Forbes a, vine L, et al (2014) Extra-hepatic manifestations of autochthonous hepatitis E infection. Aliment Pharmacol Ther 40:1282-1291.

25. Theochari E, Vincent-Smith L, Ellis C (2015) Neuralgic amyotrophy complicating acute hepatitis E infection: a rare association. BMJ Case Rep. Epub 2015 Mar 4th.

26. Décard BF, Grimm a, Andelova M, et al (2015) Hepatitis-E virus associated neuralgic amyotrophy with sustained plexus brachialis swelling visualized by high-resolution ultrasound J Neurol Sci 351:208-210.

27. Frezel N, Cassim F, Derambure P, Bocquillon P (2015) Syndrome de Parsonage-Turner: diagnostic topographique. Pratique Neurologique - FMC. 6:212-217.

28. Blasco Perrin H, Cintas P, Abravanel F, et al (2015) Neurologic disorders in immunocompetent patients with autochthonous acute hepatitis E. Emerg Infect Dis 21:1928-1934.

29. Avila JD, Lacomis D, Lam E (2015) Neuralgic amyotrophy with phrenic neuropathy associated with hepatitis E virus infection. Muscle Nerve 52(suppl):S47-S47.

30. Martínez Rodríguez L, Carvajal P, Morís G (2015) Neuralgic amyotrophy associated to hepatitis E virus infection. Med Clínica 145:462-463.

31. Silva M, Wicki B, Tsouni P, et al (2016) Hepatitis E virus infection as a direct cause of neuralgic amyotrophy. Muscle Nerve 54:325-327.

32. Bisciglia M, Van den Bergh P, Duprez T, Kabamba BM, Ivanoiu A (2016) Neuralgic amyotrophy associated with hepatitis E virus (HEV) infection: a case report. Acta Neurol Belg Epub 2016 Apr 19

33. Drave SA, Debing Y, Walter S, et al (2016) Extra-hepatic replication and infection of hepatitis E virus in neuronal-derived cells J Viral Hepat 23:512-521.

34. Cruz-Martínez A, Barrio M, Arpa J (2002) Neuralgic amyotrophy: variable expression in 40 patients. J Peripher Nerv Syst 7:198-204.

35. Hughes PD, Polkey MI, Moxham J, Green M (1999) Long-term recovery of diaphragm strength in neuralgic amyotrophy. Eur Respir J 13:379-384.

36. Podnar S (2014) Nosology of idiopathic phrenic neuropathies. J Neurol 262:558-562.

37. Mengel AM, Stenzel W, Meisel A, Büning C (2016) Hepatitis E-induced severe myositis. Muscle Nerve 53:317-320.

38. Tsairis P, Dyck PJ, Mulder DW (1972) Natural history of brachial plexus neuropathy. Report on 99 patients. Arch Neurol 27:109-117.

39. Van Eijk JJJ, Van Alfen N, Berrevoets M, Van der Wilt GJ, Pillen S, Van Engelen BGM (2009) Evaluation of prednisolone treatment in the acute phase of neuralgic amyotrophy: an observational study. J Neurol Neurosurg Psychiatry 80:1120-1124.

40. Pischke S, Hardtke s, Bode U, et al (2013) Ribavirin treatment of acute and chronic hepatitis E: a single-centre experience. Liver Int 33:722-726. 
Table 1: Cases of neuralgic amyotrophy presumed triggered by hepatitis $E$ virus

\begin{tabular}{|c|c|c|c|c|c|c|c|c|c|c|c|c|}
\hline No. & $\begin{array}{l}\text { First } \\
\text { authors } \\
\text { year }\end{array}$ & $\begin{array}{l}\text { Age } \\
(y)\end{array}$ & Sex & $\begin{array}{l}\text { Associated } \\
\text { medical } \\
\text { condition }\end{array}$ & $\begin{array}{l}\mathrm{H} \\
\mathrm{E} \\
\mathrm{V} \\
\mathrm{g}\end{array}$ & Transmission & $\begin{array}{l}\text { Hepatic biology } \\
\text { (at the onset) } \\
\text { IU/L }\end{array}$ & Pain location & $\begin{array}{l}\text { Pain } \\
\text { duration }\end{array}$ & $\begin{array}{l}\text { Associated neurologic } \\
\text { features }\end{array}$ & $\begin{array}{l}\mathrm{P} \\
\mathrm{P}\end{array}$ & $\begin{array}{l}\text { Follow-up and clinical } \\
\text { improvement }\end{array}$ \\
\hline 1 & $\begin{array}{l}\text { Fong } 2009 \\
{[11]}\end{array}$ & 53 & $\mathrm{M}$ & None & & $\begin{array}{l}\text { Travel in } \\
\text { Equator } \\
\text { (faecal-oral } \\
\text { transmission) }\end{array}$ & $\begin{array}{l}\text { ALT } 2547, \\
\text { bilirubin } 20 \\
\mu \mathrm{mol} / \mathrm{L}, \mathrm{ALP} \\
247\end{array}$ & $\begin{array}{l}\text { Shoulder, } \\
\text { radiating to } \\
\text { the chest }\end{array}$ & $6 w k$ & $\begin{array}{l}\text { Amyotrophy, proximal paresis, } \\
\text { sensory loss, abnormal } \\
\text { reflexes in the upper limbs. }\end{array}$ & $\mathrm{N}$ & $2 y /$ remission \\
\hline 2 & $\begin{array}{l}\text { Rianthavorn } \\
2010 \text { [12] }\end{array}$ & 49 & M & & $3 f$ & Travel in India & $\begin{array}{l}\text { ALT } 795, \text { AST } \\
155, \text { bilirubin } 32 \\
\mu \mathrm{mol} / \mathrm{L}, \mathrm{ALP} \\
284,\end{array}$ & Shoulders & $5 w k$ & $\begin{array}{l}\text { Amyotrophy, paresis, sensory } \\
\text { loss, abnormal reflexes in the } \\
\text { upper limbs }\end{array}$ & $\mathrm{N}$ & $10 \mathrm{mo} /$ partial improvement \\
\hline 3 & $\begin{array}{l}\text { Kamar 2011 } \\
{[13]}\end{array}$ & 38 & M & $\begin{array}{l}\text { Diabetes } \\
\text { type } 1\end{array}$ & $3 e$ & - & $\begin{array}{l}\text { ALT } 1160 \\
\text { bilirubin } \\
70 \mu \mathrm{mol} / \mathrm{L}\end{array}$ & Upper arms & - & $\begin{array}{l}\text { Amyotrophy, paresis, sensory } \\
\text { loss, abnormal reflexes in the } \\
\text { upper limbs. Left vocal cord } \\
\text { paralysis, normal functions of } \\
\text { the other cranial nerves }\end{array}$ & $\mathrm{N}$ & $18 \mathrm{mo} /$ partial improvement \\
\hline 4 & $\begin{array}{l}\text { Carli } 2012 \\
{[14]}\end{array}$ & 30 & M & None & & - & $\begin{array}{l}\text { ALT 1518, AST } \\
517, \mathrm{y}-\mathrm{GT} 59\end{array}$ & L shoulder & - & $\begin{array}{l}\text { Amyotrophy, paresis inthe } \\
\text { upper limbs. No sensory loss, } \\
\text { normal reflexes. Serpiginous } \\
\text { choroiditis in the L eye. }\end{array}$ & $\mathrm{N}$ & $\begin{array}{l}\text {, treatment by bolus of } \\
\text { corticosteroids / partial } \\
\text { improvement }\end{array}$ \\
\hline 5 & $\begin{array}{l}\text { Inghilleri } \\
2012[15]\end{array}$ & 28 & M & & & $\begin{array}{l}\text { Pork sausage } \\
\text { and ingestion } \\
\text { of raw meat }\end{array}$ & $\begin{array}{l}\text { ALT 1007, AST } \\
\text { 147, ALP } 162\end{array}$ & $\begin{array}{l}\text { Shoulders } \\
\text { and upper } \\
\text { arms }\end{array}$ & $15 d$ & $\begin{array}{l}\text { Amyotrophy, paresis, } \\
\text { abnormal reflexes in the upper } \\
\text { limbs. }\end{array}$ & $\mathrm{N}$ & - \\
\hline 6 & $\begin{array}{l}\text { Cheung } \\
2012[16]\end{array}$ & 56 & M & & & Pork sausage & $\begin{array}{l}\text { AST } 234, \\
\text { bilirubin } 30 \\
\mu \mathrm{mol} / \mathrm{L}\end{array}$ & Upper limb & $10 \mathrm{mo}$ & Paresis in a upper limb & $\mathrm{N}$ & $10 \mathrm{mo} / \mathrm{no}$ improvement \\
\hline 7 & $\begin{array}{l}\text { Peri } 2013 \\
{[17]}\end{array}$ & 53 & M & & 3 & Unknown $^{a}$ & $\begin{array}{l}\text { ALT 1768, AST } \\
696, \text { bilirubin } \\
129 \mu \mathrm{mol} / \mathrm{L}, \mathrm{g}- \\
\text { GT } 404\end{array}$ & Shoulders & 6 wk & $\begin{array}{l}\text { Proximal paresis, sensory } \\
\text { loss, abnormal reflexes in the } \\
\text { upper limbs. }\end{array}$ & $\mathrm{N}$ & $3 \mathrm{mo} /$ remission \\
\hline 8 & $\begin{array}{l}\text { Deroux } \\
2013[18]\end{array}$ & 38 & M & & & - & $\begin{array}{l}\text { ALT 1288, AST } \\
988\end{array}$ & - & - & - & $\mathrm{N}$ & $6 \mathrm{mo} /$ remission \\
\hline 9 & $\begin{array}{l}\text { Valence } \\
2014[19]\end{array}$ & 62 & M & & & $\begin{array}{l}\text { Travel in } \\
\text { Africa }\end{array}$ & $\begin{array}{l}\text { Cytolysis and } \\
\text { cholestasis } \\
2 \times N V\end{array}$ & Shoulders & - & $\begin{array}{l}\text { Paresis in the upper limbs. } \\
\text { Dysphonia }\end{array}$ & $\mathrm{Y}$ & - \\
\hline 10 & $\begin{array}{l}\text { Chirio } 2014 \\
{[20]}\end{array}$ & 32 & M & & 3 & - & ALT 10xNV & Shoulders & - & $\begin{array}{l}\text { Amyotrophy, proximal paresis, } \\
\text { sensory loss, in the upper } \\
\text { limbs. }\end{array}$ & $\mathrm{N}$ & $2 \mathrm{mo} /$ partial improvement \\
\hline 11 & $\begin{array}{l}\text { Chirio } 2014 \\
\text { [20] }\end{array}$ & 34 & M & & 3 & - & ALT 10xNV & Shoulders & - & $\begin{array}{l}\text { Amyotrophy, proximal paresis, } \\
\text { sensory loss, in the upper } \\
\text { limbs. }\end{array}$ & $\mathrm{N}$ & $2 \mathrm{mo} /$ partial improvement \\
\hline 12 & $\begin{array}{l}\text { Motte } 2014 \\
\text { [21] }\end{array}$ & 52 & M & $\begin{array}{l}\text { Prostatic } \\
\text { adenoma }\end{array}$ & $3 f$ & Unknown $^{a}$ & $\begin{array}{l}\text { ALT } 590, \text { AST } \\
179, \text { LDH } 262 \\
\text { ALP } 48, g-G T \\
212\end{array}$ & $\begin{array}{l}\text { Cervicodynia } \\
\text { to the upper } \\
\text { limbs }\end{array}$ & $2 \mathrm{mo}$ & $\begin{array}{l}\text { Amyotrophy, proximal paresis, } \\
\text { in the upper limbs. Paresis } \\
\text { and abnormal reflexes in the } \\
\text { lower limbs. No sensory loss }\end{array}$ & Y & - \\
\hline 13 & $\begin{array}{l}\text { Moisset } \\
2014[22]\end{array}$ & 36 & M & None & $3 f$ & - & $\begin{array}{l}\text { ALT 1707, AST } \\
554, \text { bilirubin } 54 \\
\mu \mathrm{mol} / \mathrm{L}, \text { ALP } \\
311, \mathrm{~g}-\mathrm{GT} 737\end{array}$ & Shoulders & - & $\begin{array}{l}\text { Proximal paresis in the upper } \\
\text { limbs. Hypophonia, dysphagia }\end{array}$ & $\mathrm{N}$ & $\begin{array}{l}6 \mathrm{mo} \text {, treatment by IVIg } 5 d \\
\text { and ribavirin } 35 d / \text { partial } \\
\text { improvement }\end{array}$ \\
\hline 14 & $\begin{array}{l}\text { Deroux } \\
2014[23]\end{array}$ & 38 & M & None & & - & $\begin{array}{l}\text { ALT 1612, AST } \\
772 \text {, (bilirubin, } \\
\text { ALP, g-GT : } \\
\text { normal) }\end{array}$ & L shoulder & - & $\begin{array}{l}\text { Amyotrophy, proximal paresis } \\
\text { in the upper limbs. }\end{array}$ & $\mathrm{N}$ & $4 \mathrm{mo} /$ partial improvement \\
\hline 15 & $\begin{array}{l}\text { Van Eijk } \\
2014[7]\end{array}$ & 37 & M & & & - & $\begin{array}{l}\text { ALT } 313, \\
\text { bilirubin } 4 \\
\mu \mathrm{mol} / \mathrm{L}, \mathrm{ALP} \\
113\end{array}$ & - & - & $\begin{array}{l}\text { Patchy bilateral brachial } \\
\text { plexus involvement }\end{array}$ & $\mathrm{N}$ & $6 \mathrm{mo} /$ partial improvement \\
\hline 16 & $\begin{array}{l}\text { Van Eijk } \\
2014[7]\end{array}$ & 35 & M & & & - & - & - & - & $\begin{array}{l}\text { Patchy bilateral brachial } \\
\text { plexus involvement }\end{array}$ & $\mathrm{N}$ & $6 \mathrm{mo} /$ partial improvement \\
\hline 17 & $\begin{array}{l}\text { Van Eijk } \\
2014[7]\end{array}$ & 40 & $\mathrm{~F}$ & & 3 & - & $\begin{array}{l}\text { ALT } 183 \text {, } \\
\text { bilirubin } 3 \\
\mu \mathrm{mol} / \mathrm{L}, \mathrm{ALP} \\
177\end{array}$ & - & - & $\begin{array}{l}\text { Patchy bilateral brachial } \\
\text { plexus involvement }\end{array}$ & $\mathrm{N}$ & 6mo / partial improvement \\
\hline 18 & $\begin{array}{l}\text { Van Eijk } \\
2014[7]\end{array}$ & 36 & M & & & - & - & - & - & $\begin{array}{l}\text { Patchy bilateral brachial } \\
\text { plexus involvement }\end{array}$ & $\mathrm{N}$ & $6 \mathrm{mo} /$ partial improvement \\
\hline 19 & $\begin{array}{l}\text { Van Eijk } \\
2014[7]\end{array}$ & 34 & M & & & - & ALT 224 & - & - & $\begin{array}{l}\text { Patchy bilateral brachial } \\
\text { plexus involvement }\end{array}$ & $\mathrm{N}$ & 6mo / partial improvement \\
\hline 20 & $\begin{array}{l}\text { Woolson } \\
2014[24]\end{array}$ & $\begin{array}{l}\text { late } \\
\text { 30th }\end{array}$ & M & & 3 & - & $\begin{array}{l}\text { ALT } 1160 \text {, } \\
\text { bilirubin } 70 \\
\mu \mathrm{mol} / \mathrm{L}\end{array}$ & - & - & Bilateral NA & $\mathrm{N}$ & $12 \mathrm{mo} /$ partial improvement \\
\hline 21 & $\begin{array}{l}\text { Woolson } \\
2014[24]\end{array}$ & $\begin{array}{l}\text { late } \\
\text { 30th }\end{array}$ & M & & 3 & - & $\begin{array}{l}\text { ALT } 319, \\
\text { bilirubin } 4 \\
\mu \mathrm{mol} / \mathrm{L}\end{array}$ & - & - & Bilateral NA & $\mathrm{N}$ & $12 \mathrm{mo} /$ partial improvement \\
\hline 22 & $\begin{array}{l}\text { Woolson } \\
2014[24]\end{array}$ & $\begin{array}{l}\text { late } \\
\text { 30th }\end{array}$ & M & & & - & - & - & - & Bilateral NA & $\mathrm{N}$ & $12 \mathrm{mo} /$ partial improvement \\
\hline 23 & $\begin{array}{l}\text { Theochari } \\
2015 \text { [25] }\end{array}$ & 65 & M & & & - & $\begin{array}{l}\text { ALT 1368, ALP } \\
167\end{array}$ & - & - & Bilateral NA & $\mathrm{N}$ & $\begin{array}{l}10 \mathrm{mo}, \text { treatment by } \\
\text { corticosteroid / remission }\end{array}$ \\
\hline 24 & $\begin{array}{l}\text { Décard } \\
2015[26]\end{array}$ & 47 & M & $\begin{array}{l}\text { Hypertensi } \\
\text { on, type } 2 \\
\text { non-insulin } \\
\text { requiring } \\
\text { diabetes }\end{array}$ & & - & $\begin{array}{l}\text { ALT 106, AST } \\
221, g-G T 239\end{array}$ & $\begin{array}{l}\text { Shoulders } \\
\text { and upper } \\
\text { arms }\end{array}$ & $\begin{array}{l}\text { Severa } \\
\text { I days }\end{array}$ & $\begin{array}{l}\text { Amyotrophy, proximal paresis } \\
\text { in the upper limbs. No sensory } \\
\text { loss, normal reflexes. }\end{array}$ & $\mathrm{N}$ & $\begin{array}{l}12 \mathrm{mo} \text {, treatment by } \\
\text { corticosteroids / partial } \\
\text { improvement }\end{array}$ \\
\hline
\end{tabular}




\begin{tabular}{|c|c|c|c|c|c|c|c|c|c|c|c|c|}
\hline 25 & $\begin{array}{l}\text { Frezel } 2015 \\
{[27]}\end{array}$ & 50 & $\mathrm{M}$ & & & - & - & L shoulder & - & $\begin{array}{l}\text { Amyotrophy, paresis, sensory } \\
\text { anomalies in } L \text { upper limb. }\end{array}$ & $\mathrm{N}$ & - \\
\hline 26 & $\begin{array}{l}\text { Blasco- } \\
\text { Perrin 2015 } \\
\text { [28] }\end{array}$ & 51 & M & & & - & $\begin{array}{l}\text { ALT 1834, AST } \\
897, \text { bilirubin } 42 \\
\mu \mathrm{mol} / \mathrm{L}, \text { ALP } \\
\text { 336, g-GT } 383\end{array}$ & Shoulder & _- & $\begin{array}{l}\text { Amyotrophy, paresis a upper } \\
\text { limb. }\end{array}$ & $\mathrm{N}$ & $\begin{array}{l}100 w k \text {, treatment by } \\
\text { ribavirin nad IVIg / } \\
\text { remission }\end{array}$ \\
\hline 27 & $\begin{array}{l}\text { Blasco- } \\
\text { Perrin 2015 } \\
{[28]}\end{array}$ & 55 & $\mathrm{~F}$ & & & _ & $\begin{array}{l}\text { ALT 1900, AST } \\
1330, \text { bilirubin } \\
15 \mu \mathrm{mol} / \mathrm{L}, \text { ALP } \\
194, \mathrm{~g}-\mathrm{GT} 182\end{array}$ & Shoulder & - & $\begin{array}{l}\text { Amyotrophy, paresis in the } \\
\text { upper limbs. }\end{array}$ & $\mathrm{N}$ & $\begin{array}{l}\text { 126wk / partial } \\
\text { improvement }\end{array}$ \\
\hline 28 & $\begin{array}{l}\text { Blasco- } \\
\text { Perrin 2015 } \\
{[28]}\end{array}$ & 56 & M & & & - & $\begin{array}{l}\text { ALT 1376, AST } \\
601 \text {, bilirubin } 15 \\
\mu \mathrm{mol} / \mathrm{L}, \text { ALP } \\
231, \mathrm{~g}-\mathrm{GT} 601\end{array}$ & Shoulder & - & $\begin{array}{l}\text { Amyotrophy, paresis, } \\
\text { abnormal reflexes in the upper } \\
\text { limbs. }\end{array}$ & $\mathrm{N}$ & 42wk / partial improvement \\
\hline 29 & $\begin{array}{l}\text { Blasco- } \\
\text { Perrin 2015 } \\
{[28]}\end{array}$ & 56 & M & & $3 f$ & - & $\begin{array}{l}\text { ALT 495, AST } \\
\text { 135, bilirubin } 17 \\
\mu \mathrm{mol} / \mathrm{L}, \text { ALP } \\
659, \text { g-GT } 740\end{array}$ & Shoulder & - & $\begin{array}{l}\text { Amyotrophy, paresis, } \\
\text { abnormal reflexes in the upper } \\
\text { limbs. }\end{array}$ & $\mathrm{N}$ & $\begin{array}{l}16 w k \text {, treatment by ribavirin } \\
\text { and IVIg / partial } \\
\text { improvement }\end{array}$ \\
\hline 30 & $\begin{array}{l}\text { Dartevel } \\
2015[6]\end{array}$ & 54 & $\mathrm{M}$ & $\begin{array}{l}\text { Familial } \\
\text { history : NA } \\
\text { in his son } \\
\text { and } \\
\text { suspected } \\
\text { in his } \\
\text { daughter }\end{array}$ & $3 f$ & Unknown $^{\mathrm{a}}$ & $\begin{array}{l}\text { ALT 1036, AST } \\
259, \text { ALP 180, } \\
\text { g-GT } 334\end{array}$ & $\begin{array}{l}\text { Cervicodynia } \\
\text { to the upper } \\
\text { limbs }\end{array}$ & - & $\begin{array}{l}\text { Amyotrophy, proximal paresis, } \\
\text { sensory anomalies, abnormal } \\
\text { reflexes in the upper limbs. }\end{array}$ & $\mathrm{Y}$ & $\begin{array}{l}10 \mathrm{mo} \text {, treatment by } \\
\text { corticosteroids / partial } \\
\text { improvement, persistence } \\
\text { of orthopnea }\end{array}$ \\
\hline 31 & $\begin{array}{l}\text { Dartevel } \\
2015[6]\end{array}$ & 54 & M & $\begin{array}{l}\text { Chronic } \\
\text { alcoholic } \\
(10 \mathrm{~g} / \mathrm{d})\end{array}$ & $3 f$ & Unknown $^{a}$ & $\begin{array}{l}\text { ALT 812, AST } \\
332, \text { bilirubin } 8 \\
\mu \mathrm{mol} / \mathrm{L}, \text { ALP } 89, \\
\text { g-GT } 66\end{array}$ & $\begin{array}{l}\text { Upper L limb, } \\
\text { scapular } \\
\text { muscles and } \\
\text { lower limbs }\end{array}$ & - & $\begin{array}{l}\text { Amyotrophy, paresis, sensory } \\
\text { loss, in the } L \text { upper limb and } \\
\text { lower limbs. Normal reflexes }\end{array}$ & $\mathrm{N}$ & 1y / partial improvement \\
\hline 32 & $\begin{array}{l}\text { Dartevel } \\
2015[6]\end{array}$ & 40 & $\mathrm{~F}$ & $\begin{array}{l}\text { Hashimoto' } \\
\text { s thyroiditis }\end{array}$ & $3 f$ & Unknown $^{\text {a }}$ & $\begin{array}{l}\text { ALT 1305, AST } \\
438, \text { ALP 208, } \\
\text { g-GT 170, }\end{array}$ & $\begin{array}{l}\text { Shoulders } \\
\text { irradiating in } \\
\text { the upper } \\
\text { limbs }\end{array}$ & - & $\begin{array}{l}\text { Proximal paresis, sensory } \\
\text { loss, in the upper limbs. }\end{array}$ & $\mathrm{N}$ & $\begin{array}{l}\text { 1y, (treated by IVIg 3d) / } \\
\text { partial improvement }\end{array}$ \\
\hline 33 & $\begin{array}{l}\text { Dartevel } \\
2015[6]\end{array}$ & 51 & $\mathrm{~F}$ & $\begin{array}{l}\text { Crohn's } \\
\text { disease, } \\
\text { NA 6y } \\
\text { before (with } \\
\text { phrenic } \\
\text { paralysis), } \\
\text { daughter } \\
\text { had } \\
\text { developed } \\
\text { NA }\end{array}$ & & Unknown $^{\mathrm{a}}$ & $\begin{array}{l}\text { normal (1wk } \\
\text { after onset } \\
\text { symptoms) }\end{array}$ & $\begin{array}{l}\text { Cervicodynia, } \\
\text { R shoulder }\end{array}$ & - & Paresis in R upper limb. & $\mathrm{Y}$ & $\begin{array}{l}10 \mathrm{mo} \text {, treatment by IVIg / } \\
\text { good improvement of the R } \\
\text { shoulder, but persisted } \\
\text { dyspnea }\end{array}$ \\
\hline 34 & $\begin{array}{l}\text { Dartevel } \\
2015[6]\end{array}$ & 59 & $\mathrm{M}$ & $\begin{array}{l}\text { Type-2 } \\
\text { diabetes }\end{array}$ & & Unknown $^{a}$ & $\begin{array}{l}\text { ALT 88, AST } \\
32, \text { g-GT } 365\end{array}$ & $\begin{array}{l}\text { Cervicodynia, } \\
\text { shoulders }\end{array}$ & - & $\begin{array}{l}\text { Amyotrophy, distal paresis in } \\
\text { the upper limbs. Normal } \\
\text { reflexes. No sensory loss }\end{array}$ & $\mathrm{Y}$ & - \\
\hline 35 & $\begin{array}{l}\text { Avila } 2015 \\
{[29]}\end{array}$ & 52 & $\mathrm{M}$ & & & - & $\begin{array}{l}\text { Increased } \\
\text { transaminases }\end{array}$ & Shoulders & - & $\begin{array}{l}\text { Paresis, abnormal reflexes, in } \\
\text { the upper limbs. }\end{array}$ & $\mathrm{Y}$ & $\begin{array}{l}5 \mathrm{mo} \text {, treatment by } \\
\text { corticosteroids / partial } \\
\text { improvement, with } \\
\text { persisted orthopnea }\end{array}$ \\
\hline 36 & $\begin{array}{l}\text { Martinez } \\
\text { Rodriguez } \\
2015 \text { [30] }\end{array}$ & 41 & $M$ & $\begin{array}{l}\text { not } \\
\text { significant }\end{array}$ & & Unknown $^{a}$ & $\begin{array}{l}\text { ALT 1270, AST } \\
\text { 481, bilirubin } 68 \\
\mu \mathrm{mol} / \mathrm{L}, \text { ALP } \\
241, \mathrm{~g}-\mathrm{GT} 1189\end{array}$ & R shoulder & - & $\begin{array}{l}\text { Paresis of } \mathrm{R} \text { upper limb. No } \\
\text { sensory loss, normal reflexes. }\end{array}$ & $\mathrm{N}$ & - \\
\hline 37 & $\begin{array}{l}\text { Silva } 2016 \\
{[31]}\end{array}$ & 51 & $\mathrm{M}$ & & 3 & - & $\begin{array}{l}\text { ALT 2579, AST } \\
\text { 1234, normal } \\
\text { bilirubin, ALP } \\
\text { 167, g-GT } 308\end{array}$ & $\begin{array}{l}\text { Proximal } L \\
\text { leg, } L \\
\text { hemithorax } \\
\text { and L arm }\end{array}$ & $2 w k$ & $\begin{array}{l}\text { Paresis, distal sensory loss, in } \\
\text { the upper limbs. }\end{array}$ & $\mathrm{N}$ & $\begin{array}{l}12 \text { mo, treatment by IVIg / } \\
\text { partial improvement }\end{array}$ \\
\hline 38 & $\begin{array}{l}\text { Bisciglia } \\
2016[32]\end{array}$ & 50 & $\mathrm{~F}$ & & 3 & Unknown $^{a}$ & $\begin{array}{l}\text { ALT 2086, AST } \\
812, \text { ALP 152, } \\
\text { g-GT } 98\end{array}$ & L upper limb & - & $\begin{array}{l}\text { Distal paresis, distal sensory } \\
\text { loss, in L upper limb. Normal } \\
\text { reflexes }\end{array}$ & $\mathrm{N}$ & $\begin{array}{l}\text { 9mo, treatment by cortico } \\
\text { steroids } 3 \mathrm{mo} \text { ( } 3 \mathrm{mo} \text { after } \\
\text { onset of symptoms) / partial } \\
\text { improvement }\end{array}$ \\
\hline 39 & Our case & 42 & $\mathrm{M}$ & $\begin{array}{l}\text { Malaria 20y } \\
\text { ago }\end{array}$ & $3 f$ & Pork sausage & $\begin{array}{l}\text { ALT 1658, AST } \\
642 \text {, bilirubin } 34 \\
\mu \text { mol/l, ALP } \\
\text { 181, g-GT } 285\end{array}$ & $\begin{array}{l}\text { Cervico- } \\
\text { thoracic para } \\
\text { spinal }\end{array}$ & $10 d$ & Cf. case report & $\mathrm{Y}$ & $\begin{array}{l}\text { 9mo / partial improvement, } \\
\text { dyspnea persisted }\end{array}$ \\
\hline
\end{tabular}

ALT=alanine aminotransferase; ; ALP=alkaline phosphatase; AST=aspartate aminotransferase; $C S F=$ cerebrospinal fluid; $g$-GT=gamma glutamyl transferase; HEV g.=heptatitis E virus genotype; L=left; LDH=lactate dehydrogenase; Nv=normal value; $P P=$ phrenic paresis; $R=$ right; $Y / N=y e s / n o ;$

a Unknown=No source for HEV transmission, including travel, cases in the family, eating undercooked pork or drinking unsafe water 
Table 2: Parameters of neuralgic amyotrophy induced by hepatitis $E(A)$ and neuralgic amyotrophy with phrenic paresis (B) in the review of the literature, compared with the largest cohort of NA, described by Van Alfen and Van Engelen. 2006

\begin{tabular}{llll}
\hline & Group A (INA+HEV) & Cohort & p-value \\
\hline Age, mean \pm SD [n] & $46.0 \pm 9.8[36]$ & $41.3[194]$ & 0.12 \\
Gender M/F & $34 / 5$ & $136 / 63$ & $\mathbf{0 . 0 1 7}$ \\
$\begin{array}{l}\text { Phrenic paresis, \% (Y/N) } \\
\text { Bilateral and asymmetric NA, \% (Y/N) }\end{array}$ & $18.0 \%(7 / 32)$ & $6.6 \%(13 / 186)$ & $\mathbf{0 . 0 2 8}$ \\
$\begin{array}{l}\text { Pain characteristics } \\
\text { Pain less, \% (Y/N) }\end{array}$ & $86.8 \%(33 / 5)$ & $27.7 \%(67 / 175)^{\mathrm{a}}$ & $<\mathbf{0 . 0 0 0 1}$ \\
$\begin{array}{l}\text { Duration of pain if it was precised, [n] or \% } \\
\text { <24h }\end{array}$ & $0 \%(0 / 29)$ & & \\
1-7days & {$[0]$} & $3.7 \%(9 / 237)^{\mathrm{a}}$ & \\
7-60days & {$[0]$} & $4.9 \%$ \\
$>$ 60days & {$[6]$} & $22.7 \%$ \\
Clinis & {$[2]$} & $62.4 \%$ &
\end{tabular}

Clinical improvement,

$\%[n]$ (median of the follow-up)

No improvement

Partial improvement

Remission

$3.1 \%[1]$ (10mo)

Average transaminases, IU/L [ $\mathrm{n}$ ]

$81.3 \%[26](9 \mathrm{mo})$

ALT

$15.6 \%$ [5] (10mo)

AST

1093 [32]

510 [23]

\begin{tabular}{|c|c|c|c|}
\hline & $\begin{array}{l}\text { Group B } \\
\text { (INA+phrenic paresis) }\end{array}$ & Cohort & p-value \\
\hline Age, mean $\pm S D[n]$ & $52.9 \pm 13.0[42]$ & $41.3[199]$ & $<0.0001$ \\
\hline Gender M/F & $33 / 9$ & $136 / 63$ & 0.19 \\
\hline $\begin{array}{l}\text { Phrenic paresis lateralisation, \% [n] } \\
\text { Bilateral } \\
\text { Unilateral }\end{array}$ & $\begin{array}{l}51.3 \%(20) \\
48.7 \%(19)\end{array}$ & & \\
\hline $\begin{array}{l}\text { Pain characteristics } \\
\text { Pain less, \% }(\mathrm{Y} / \mathrm{N}) \\
\text { Duration if pain occurs, \% [n] }\end{array}$ & $23.8 \%(5 / 16)$ & $3.7 \%(9 / 237)^{a}$ & 0.002 \\
\hline $\begin{array}{l}<24 \mathrm{~h} \\
1 \text {-7days } \\
7-60 \text { days } \\
>60 \text { days }\end{array}$ & $\begin{array}{l}6.25 \%[1] \\
18.75 \%[3] \\
56.25 \%[9] \\
18.75 \%[3]\end{array}$ & $\begin{array}{l}4.9 \% \\
22.7 \% \\
62.4 \% \\
10 \%\end{array}$ & \\
\hline $\begin{array}{l}\text { Clinical improvement } \\
\% \text { [n] (median of the follow-up) } \\
\text { No improvement } \\
\text { Partial improvement } \\
\text { Remission }\end{array}$ & $\begin{array}{l}33.3 \%[12](12 \mathrm{mo}) \\
47.2 \%[17](12 \mathrm{mo}) \\
19.4 \%[7](16 \mathrm{mo})\end{array}$ & & \\
\hline
\end{tabular}

$\mathrm{ALT}=$ =alanine aminotransferase; $\mathrm{AST}=$ aspartate aminotransferase; ; $\mathrm{HEV}=$ hepatitis $E$ virus; INA=idiopathic neuralgic amyotrophy; $\mathrm{mo}=\mathrm{month} ; \mathrm{Y} / \mathrm{N}=\mathrm{yes} / \mathrm{no} ;{ }^{\mathrm{a}}$ on 246 cases including hereditary $\mathrm{NA}$ 